\title{
Physical education and sport teachers' health: from expressed ill-being to hindrances of action
}

\author{
Coutarel, Fabien*, and Fiard, Jacques \\ Université de Clermont, Université Blaise Pascal, ACTé, EA 4281, Clermont-Ferrand, France
}

\begin{abstract}
The researches that specifically analyse the working conditions of teachers are few in the ergonomic literature. Our research relates more specifically to teachers of physical education and sports in french context of college. The research project described here includes both a quantitative exploratory survey (218 respondents) and qualitative case studies (interviews and observation), using the general framework of Activity Ergonomics. The results of this exploratory work tend to emphasize the importance of collective and organizational dimensions in the experience of teachers' physical education and sports. Specifically, in a perceived context of degradation of working conditions and accumulation of constraints, the collective and local ability to negotiate the various constraints on the activity appears to be a protective factor. This power to act, these margin of manoeuvre could be a relevant topic for future research.
\end{abstract}

Keywords: Margin of manoeuvre, Health at work, Organisational constraints, Collective Work, Psychosocial Health

\section{Introduction}

The research that analyze the working conditions of teachers are few in the literature ergonomic, and specifically in the tradition of the activity ergonomics [1]. A tradition of works is concerned with the interest in occupational training of the ergonomic activity analysis [eg, 2, 3, 4, 5, 6]. The various symposia at major meetings of Ergonomics (IEA, SELF) reflect this dynamic both nationally and internationally since the 1990s. Some of these researches deal specifically with the activity of teaching in the education system [eg, 7, 8, 9, 10, 11, $12,13,14,15]$.

In the French educational system, the teacher of physical education and sports (EPS) performs its work in often specific (spaces, ways of mobilizing the students, collective dynamics between EPS teachers ...). Work-research on this specific population and questioning the conditions of practice are few. The common discourse emphasizes the constraints of noise, equipment and security issues.
However, the experienced trainers of young teachers visiting schools emphasize an ill-being of teachers, which does not seem to directly related to these constraints The research project assumes that the constraints commonly identified for the EPS teachers is insufficient to understand their difficulties. It is nevertheless a requirement to improve work situations.

\section{Method}

The research project is based on two components:

- A survey conducted in December 2008 to explore the working conditions perceived as problematic and those perceived to be favorable for the construction of health. 218 EPS teachers have responded (108 men and 110 women equally distributed by age groups).

- A qualitative approach aimed at furthering some of the results of the survey. Twenty interviews were conducted with teachers of the academy in question by a teacher trainer. Simultaneously a

\footnotetext{
${ }^{*}$ Corresponding author. E-mail: Fabien.Coutarel@univ-bpclermont.fr. Université Blaise Pascal, UFR STAPS, BP 104, Les Cézeaux, 63172 Aubière Cédex.
} 
master's thesis of ergonomics in 2010 [16] analyzed two groups of EPS teachers. These two groups were chosen with the education academic inspectors in two different schools: one (A) where teachers would "go quite well" and the other (B) where they would "be in difficulty". This second component is currently being finalized.

\section{Results}

The quantitative survey shows first a general positive perception of their work by the PE teachers. For example, PE teachers consider themselves in good form broadly (160/218). They are convinced $(85 \%)$ of the beneficial effects of EPS they teach. A large majority of them said he chose this profession by vocation (186 of 218) and many people are still heavily engaged in their work (151).

These results to general questions about the job seem contradictory to those from more specific questions. Note for example that $90 \%$ of respondents said sometimes or frequently after tiring sessions. The emphasis of problem behaviors of students (118 of 218), loss of appetite for the effort (115 of 218) or discipline (127 of 218), inattention (89 of 218) or a number of students per class is too high (64.5\%). $1 /$ 3 of respondents expressed forms of disillusionment, weariness and stress, $64.4 \%$ of teachers consider unacceptable workloads. This includes daily loads "outside job" (participation in various councils, working groups, meetings, etc ...).

3 results more surprising given the literature have questioned:

1. Complaints about environmental conditions (cold, rain, noise ...) are not very many (25\%);

2. collective work often appears as a difficulty of the job: $58.3 \%$ of respondents thus refute the idea of a cohesive team within each school, $77.6 \%$ think that this will become worse over time and $80.3 \%$ of them consider the collective work as a factor of exhaustion;

3. Both national and local guidelines produced by the educational system and the administration of the schools are perceived as a source of additional constraints.

Qualitative analyses were then designed to understand more precisely the subjective relationship of the teacher to group of colleagues, to the institution of education and to the administration of schools. These analyses are still ongoing. Initial results highlight the tight constraints perceived around the EPS teachers and unable to act experienced in the daily work to redefine their professional practice. This could be found through the analysis of various disciplinary and interdisciplinary collective projects initiated.

Team B is investing heavily in a group work with colleagues. This allows him to construct and negotiate collective strategies in favor of a more consistent behavior and strategies of teachers and students face in front of the school administration. This seems to allow the group more flexibility in the management of activities: schedules, distribution of sports facilities, organization of training courses outside of school, participation in meetings and councils school ...). The analysis of projects conducted underlines the capacity built to derogate from the usual framework established by different sources of prescription of work. The development of "occupational activities in and by the transgression" seems to us an essential outcome.

\section{Discussion}

The accurate investigation of professional activity of EPS teachers highlights the difficulties that the general discourse of actors on the job do not usually described. For this reason, the ergonomic analysis of the activity of teachers seems essential and complementary to the quantitative surveys. Evilbeing identified in the survey certainly reflects the perception of a deterioration of working conditions, where the margin of manoeuvre of teachers is decisive for their health. One can imagine that this is also a performance issue with the quality of teaching and student learning. All this does not seem directly related to noise constraints, equipments or facilities and security.

Our case study leads us to propose that the inability to act according to own collective norms may be related to fatalism found in the general discourse, which also notes a lesser performance of EPS teachers. They combine the feeling of not having the resources for "good work" to their state of exhaustion. The "professional development in and by the transgression" seems to be a local response that works. However, and if this result would be confirmed by next researches, it is useful to consider its fragility. 
Overall, these results reinforce the relevance of an approach based on collective and organizational aspects of teachers' activity. From this point of view, the specifics of discipline taught (EPS) would not constitute a central element of discussion and the results could also challenge teachers from other disciplines. Finally, these results seem characteristic of situations known as "amputation of the power to act" [16], where frequent cleavages between the teacher and his colleagues, between group and administration, contribute to reducing the scope for action.

\section{References}

[1] F. Daniellou and P. Rabardel, Activity-oriented approaches to ergonomics: some traditions and communities, in: Theoretical Issues in Ergonomics Science, 6, 5 (2005), 353-357.

[2] L'ergonomie, le formateur et le travail, In : Education Permanente, 124 (1995)

[3] Analyses du travail et formation, in: Education Permanente, 166 (2006).

[4] D. Berthelette, M. Lacomblez, and C. Teiger, La conception de programmes de formation à et par l'analyse du travail: réflexion sur des travaux en cours en ergonomie, en psychologie du travail et en recherche évaluative, in: Actes du colloque «Recherche et Ergonomie», Toulouse, 1998.

[5] C. Chatigny, and C. Teiger, L'ergonomie et la construction des savoirs professionnels : analyse de l'apprentissage du métier de l'agent d'exploitation des eaux, in: Actes du $31 \mathrm{e}$ Congrès de la SELF, Intervenir par l'ergonomie, Bruxelles, 1996, pp. 300-306.

[6] P. Rabardel, L'ergonomie et la formation : quelles analyses du travail ?, in: Actes du 26e Congrès de la SELF, Montréal, 1990.

[7] C. Teiger and M. Lacomblez, Apport de l'ergonomie à la formation des opérateurs concernés par les transforma- tions des activités de travail, in: Actes du 32e Congrès de la SELF, Recherche, Pratique, Formation en Ergonomie, 1997, pp. 263-275.

[8] C. Chatigny and N. Vézina, L'analyse ergonomique de l'activité de travail: un outil pour développer les dispositifs de formation et d'enseignement, in: Y. Lenoir and P. Pastré (Éds.), Didactique professionnelle et didactiques disciplinaires en débat, Toulouse, Octares Edition, 2008.

[9] D. Cau-Bareille, Vécu du travail et santé des enseignants en fin de carrière: une approche ergonomique, Centre d'études de l'emploi, 56 (2009).

[10]K. Messing and A. M. Seifert, On est là toutes seules. Contraintes et stratégies des femmes en contrat à durée déterminé dans l'enseignement des adultes, in: Travailler, 7 (2011), 147166.

[11]K. Messing, A. M. Seifert, and E. Escalona , Reine de la salle de classe: Stratégies des enseignantes de niveau primaire, in : A. Soares (dir.), Stratégies de résistance et travail des femmes, L'Harmattan, 1997, pp. 69-105.

[12]N. Lang, Comprendre et transformer les situations de travail quand on est enseignant en Lycée professionnel? Les apports d'une formation à l'analyse du travail, in: Formation Emploi, 74 (2001), 53-66.

[13]K. Launis and A. Koli, Le bien-être au travail en mutation chez les enseignants - une nouvelle approche guidée par la théorie culturelle et historique de l'activité, In: PISTES, 6, 2 (2004).

[14]N. Delvolvé and A. Margot, Le travail de l'enseignant du point de vue de l'ergonomie, in: Psychologie et Éducation, 44 (2001), 43-54.

[15]N. Delvolvé and M-T. Poudou-Zerbato, Didactique, pédagogie, Ergonomie, quelle complémentarité ?, in: Actes du colloque «Recherche et Ergonomie», Toulouse, 1998.

[16]D. Granier, Etude de l'influence des dimensions organisationnelles et collectives de l'activité professionnelle des enseignants d'EPS sur la performance et sur la santé de ces travailleurs. Mémoire de Master 1 d'Anthropologie des Pratiques Corporelles, Université Blaise Pascal, France, 2010.

[17]Y. Clot, Travail et pouvoir d'agir, Presses Universitaires de France, 2008. 